\title{
Utilization of Network Technologies in Market Information Exchange in Kisumu City, Kenya
}

\author{
Susan R. A. Rabare ${ }^{1}$, George G. Wagah ${ }^{2} \&$ George M. Onyango ${ }^{3}$ \\ ${ }^{1}$ Assistant Registrar/Lecturer, Maseno University, Maseno, Kenya \\ ${ }^{2}$ Senior Lecturer, Dept. of Urban and Regional Planning, Maseno University, Maseno, Kenya \\ ${ }^{3}$ Professor of Urban Planning, Dept. of Urban and Regional Planning, Maseno University, Maseno, Kenya \\ Correspondence: George G. Wagah, Dept. of Urban and Regional Planning, Maseno University, P.O. Box \\ 333-40105, Maseno, Kenya. Tel: 254-733-627-105. E-mail: ggwagah@yahoo.com
}

Received: March 29, 2014

Accepted: May 1, 2014 Online Published: November 24, 2014

doi:10.5539/ijms.v6n6p81

URL: http://dx.doi.org/10.5539/ijms.v6n6p81

\begin{abstract}
In today's marketplaces, information products are vital tools with which city governments and businesses can optimize their capacities and make cities more livable. Cities should treat their digital infrastructure and the data as a market creation asset that can propel economic development. Despite the opportunities posted by network technologies, optimal utilization remains a challenge for local authorities and businesses in developing countries. This paper examines the utilization of network technologies in market information exchange in Kisumu City of Kenya based on a case study which involved stratified random sampling of 40 staff of Kisumu City Council and systematic sampling of 260 small business enterprises. The study shows that $72 \%$ of business respondents and $77 \%$ of City Council respondents used some form of network technology, a clear indication that the technologies has been adopted. The major technology trends include use of internet at $54 \%$ by the business enterprises and $67 \%$ by the council staff. Technology has contributed positively to both work and business despite the impediments which include financial constraint and lack of awareness. The Council and the businesses have great opportunities for information exchange through technology. It is discovered that network technologies are used more for non market information exchange, an indication why the technology adoption for business has not moved beyond the substitution stage. It is recommended that the Council sensitizes the businesses on network technologies and the potentials therein. The government should explore installation of cheaper and faster internet connectivity as well as enact viable policies to propel market information exchange.
\end{abstract}

Keywords: network technologies, utilization, market information, exchange

\section{Introduction}

Today's digitized world is in dire need of network technologies and information products as a means to catalyze information exchange and make businesses vibrant and cities livable. In describing the transition from traditional to information markets, Simard (2005) uses a metaphor of autonomous providers and users exchanging information in place of sellers and buyers trading in goods and services. Webb, Buscher and Giles, (2011), states that, information products are the tools with which cities can mine the surplus capacity in the city's infrastructure and unlock citizen's creativity to make cities more livable. According to Linde and Stock (2011), the information market is the market for digital information distributed via networks. Network technologies refer to a collection of computers and other hardware interconnected by communication channels that allow sharing of resources and information. The use of technology and networked infrastructure to improve economic, environmental and political efficiency as well as enable social cultural urban development is critical in today's techno savvy society. With 10 percent increase in high-speed internet connections, economic growth increases by 1.3 percent (World Bank, 2009).

In the world over, use of network technologies has proven vital in enhancement of information exchange and efficiency of service delivery. In a study of sixty nine upper and lower tier English local authorities, a positive change was observed in the way regeneration activities were undertaken following the establishment of an information system (Foley, Alfonso, \& Wiseman., 2007). In Naga City in Philippines, information technology have been successfully adopted to develop, control and assess functions within the City Council (NCDP, 2000). 
With the implementation of a management information system, Falsalabad City Management was able to achieve speedy service delivery, increased access to service agencies, remote control and transactions, increased transparency, linkages across organizations and increased awareness of interdependencies (Alam et al., 2008).

The rise of mobile telephony in particular and its associated applications are the most striking examples of information technology development in Africa, with a penetration rate of $41 \%$ at the end of 2010, a growth of more than $200 \%$ from 2005 levels (Kwadwo \& Mekonnen, 2012). Market information system and traders' organization of West Africa (MISTOWA) in partnership with the private sector, developed a platform, www.tradenet.biz, to exchange market information in real time on-line or through cellular phones on market prices, buy and sell offers and trader contact information (Davis \& Addom, 2010). In Nigeria cassava growers received market information through a new initiative called the integrated Cassava Project based on mobile phones and internet (Pyramid Research, 2010). In Mozambique, Neun (2006) and Jenson, Myers and Southwood, (2004) have shown that farmers with access to market information obtained higher farm prices. The Mozambique agricultural marketing service (SIMA) collects and disseminates nation-wide and provincial data on market prices, product processing and availability through a variety of media including text messages, email and internet. In an examination of the implementation of the computerized local Authority Integrated Financial Operational Management System (LAIFOMS) in two local authorities in Kenya it was revealed that $70 \%$ of consumers thought that LAIFOMS implementation had improved responsiveness to consumers while $80 \%$ of all interviewed consumers being of the view that computerization had improved accountability in operations of the councils (Waema \& Mitullah, 2007).

Despite the significant growth of ICT over the past decade, Africa still lags behind other regions both in terms of percentage of people with access to the full range of communications services and the amounts and manner in which they can be used (ITU, 2010). Beynon-Davies, (2002) identified six types of information technology failure as technical, project, organizational, environmental, developmental and user failure. Africa as a whole continues to lag behind other regions of the world primarily as a result of the high cost of services (Calandro, Gillwald, Moyo, \& Stork, 2010). In general, high cost of services is the very reason that continues to inhibit the uptake of ICT services and their usage by consumers throughout Africa (Gillwald \& Stock, 2008). Small enterprises are generally seen as being at a disadvantage to larger businesses. They are characterized by limited availability of resources in terms of time, money and expertise (Wymer \& Regan, 2005). Their inferior technology and managerial capabilities have often shown to be a constraint on their effective use of new technologies (Caldeira \& Ward, 2002). Whereas ICT is not a panacea for all development problems, it offers enormous opportunities to small enterprises.

Inspite of the challenges to use of technology in information exchange there exists a lot of potential strengths of use of IT to enhance market information sharing, this study sought to establish utilization of IT in information exchange by the local Authority and the small enterprises (SEs) in Kisumu City's Central Business District and examine the inhibitors to use of network technologies in the market information exchange. The livelihood of a vast majority of people in Kisumu City is highly dependent on income from small enterprises. Therefore the development of reliable and timely market information is vital for the development of the county and the country at large and provides a basis for traders to make informed marketing decisions.

The findings of this report show the extent of utilization of the network technologies in market information exchange by small businesses and Kisumu City Council. It examines the inhibitors to use of the technologies in information exchange and makes several recommendations to enhance market information accessibility. The study makes a discovery on the preferred information exchange through the network technologies and an indication why the technologies have remained in the substitution stage.

\subsection{Study Area}

Kisumu is a port city in western Kenya with a population of 968,909 (KNBS, 2009) and the headquarters of Kisumu County. It has developed progressively from a railway terminus and internal port in 1901, to become the leading commercial, industrial, communication and administrative centre in the Lake Victoria basin. The population targeted was two fold, the Kisumu City Council staff with a population of 1000 and the businesses within the Central Business District, with a population of 4000 of which three quarter are small enterprises as established from Kisumu City Council revenue section.

\subsection{Methodology}

Data was collected between October and December, 2012. Questionnaires were administered to SEs and the KCC staff. Key informants interview was held with KCC ICT coordinator. Kisumu City Council website and social networks were reviewed as well as several relevant literature material. Sampling from staff was obtained through stratified purposive sampling of 40 respondents from 4 strata namely; Finance \& Human Recourse; 
Planning \& Environment and Inspectorate, Engineering \& IT departments. The departments were purposively selected due to their relevance to the study. Systematic sampling of every $10^{\text {th }}$ element was used to sample 260 SEs of up to 4 employees within the CBD of Kisumu City. Data was analysed using both qualitative and quantitative methods that included univariate analysis, descriptive coding technique and content analysis. The sample size for the SEs was established as illustrated below.

Sample size formula for $\mathrm{n}$ is:

$$
N z^{\wedge} 2 p q /\left(E^{\wedge} 2(N-1)+z^{\wedge} 2 p q\right)
$$

Where: $\mathrm{N}$ (population size $=4000), \mathrm{z}($ confidence level $=1.96 / 95 \%), \mathrm{E}(+-$ error $=0.05), \mathrm{p}($ probability $=0.5), \mathrm{q}$ $(=0.5)$

Required sample size $=351$

$3 / 4$ of $351=263$

\section{Results and Discussions}

\subsection{Network Technologies Utilization}

Kisumu City Council was connected to the public through their website, www.kisumucitycouncil.org.ke. The website interactions were possisible through emails provided as well as through social networks such as Facebook and Twitter. Most of the issues raised through the emails and social networks were complaints on gabbage collection, dumb sites, land rates and infrastructure. Kisumu City Council also offers various forms of communication through their website, www.citycouncilofkisumu.org.ke.com. A review of the website revealed that the Council provided background information and strategic objective of the Council, downloads included single business permits application, fees and charges 2009. The departments lists had further links for instance to download of documents such as the building submission form and certificate of structural design form. The website did not provide any interaction avenue for feedback by viewers to the site but had contact addresses that included email addresses and social networks such as Facebook and Twitter addresses, citycouncilofKisumu and twitter@kisumuctcouncil respectively. The website also had option for search, announcement, partners and details for fees and charges for all categories of traders within the City Council. Other information provided through the website included Council by-laws. The option to check land rates option was available but not enabled. The photo gallery available on the website on $29^{\text {th }}$ December 2012 was last updated on $9^{\text {th }}$ February 2010, an indication that the website was not under frequent review and update.

Network technologies can provide city leaders with tools for widespread citizen engagement and new ways of interacting and collaborating for improved service delivery and enhanced market accessibility. For instance In the United States, CiRM technologies were used to the operation Call Centers, which are centralized local government public information entities charged with taking nonemergency service requests from citizens. The Centres provides citizens with 24 hour access to government information and non-emergency services through various portals including, telephone line, website and blog (Webb et al., 2011). Kisumu City Council has not adopted use of blog and other portals like use of text messages through the mobile phone networks.

Facebook page visited on $31^{\text {st }}$ December, 2012 revealed a complaint on land rate posted by a resident on $8^{\text {th }}$ December was responded to on $31^{\text {st }}$ December, indicating a delay in response to customer complaints by the council. The Facebook page also had announcements on the $7^{\text {th }}$ edition of Safaricom Kisumu marathon as well as tourist sites and wildlife in Kisumu County The Twitter pay was also viewed and was found to be active with seventeen followers on $31^{\text {st }}$ December 2012.The Kisumu City Council had evidently made a good attempt to share information through their website and other online portals.

Table 1. Summary of responses on utilization of some network technologies

\begin{tabular}{lll}
\hline & \multicolumn{2}{c}{ Yes Responses } \\
\cline { 2 - 3 } Item & Small Enterprises \% & Council Staff \% \\
\hline Have access to any form of Internet connectivity & 82 & 77 \\
Use of Internet & 54 & 67 \\
Any training on information technology & 45 & 55 \\
Use of network technologies for market information exchange & 24 & 30 \\
Use of network technologies for social/non market information exchange & 76 & 70 \\
\hline
\end{tabular}


As shown in table 1, majority of the respondents had access to internet but utilization of the facility was much less amongst the business enterprises. It was discovered that both the businesses and the Council staff the used the internet and mobile telephony more for non market information exchange than market information exchange or for business purposes.

\subsection{Network Technologies and Governance}

The research findings indicate that $77 \%$ of Council staff and $72 \%$ of SEs respondents used some form of network technologies. This included use of internet, intranet and mobile telephony. The SEs mainly used the third generation $(3 \mathrm{G})$ mobile telephony which offers data rates of more than $144 \mathrm{Kbit} / \mathrm{s}$, thereby opening the door to multimedia uses such as video transmission, video-conferencing or high-speed internet access. The findings also revealed that $60 \%$ of Council respondents had access to the Internet at work while $48 \%$ were networked through the Intranet.

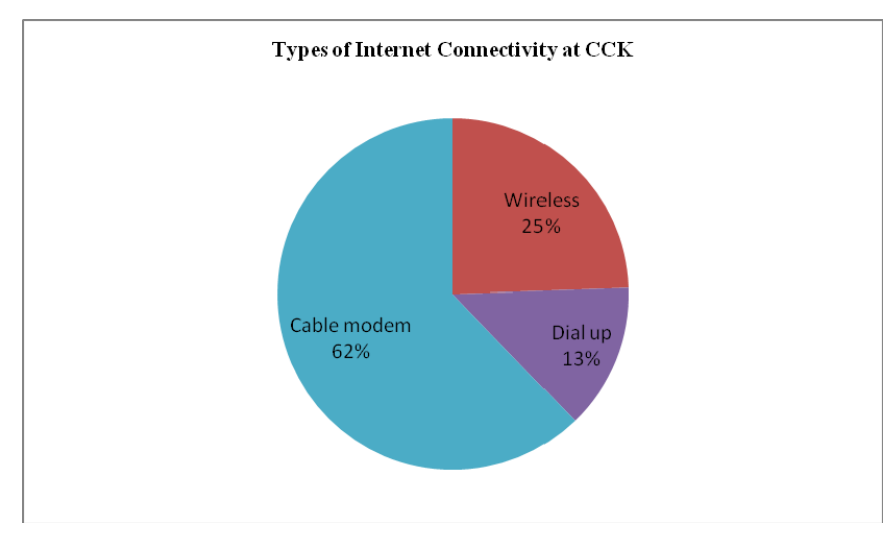

Figure 1. Type of internet connectivity

As shown in figure 1, the Council had most of its internet connectivity via cable modem or dial-up technology, an analog internet connection which is economical but slow. Dial-up is an analog connection because data is sent over an analog, public-switched telephone network.

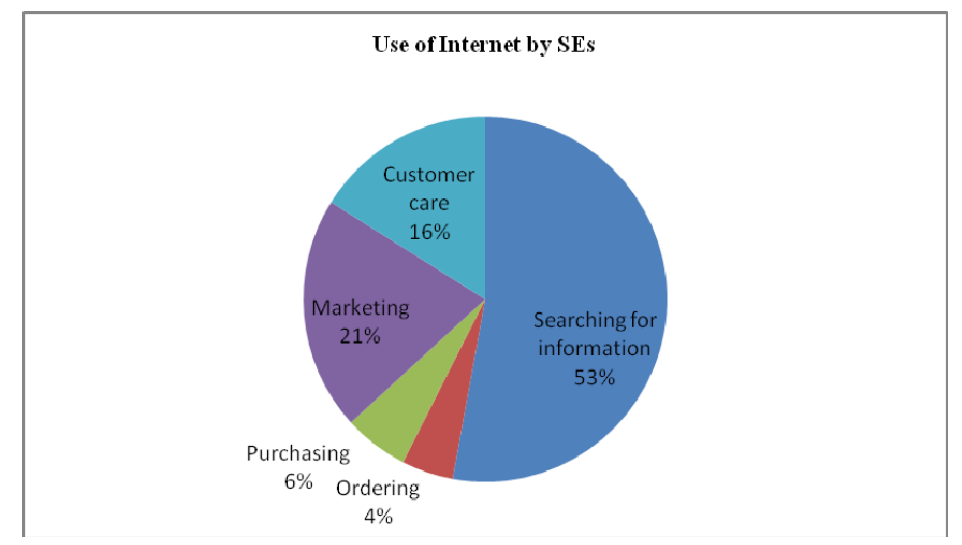

Figure 2. Uses of internet by small enterprises

The total number of internet subscriptions in Kenya increased to 4.7 million by end of December 2010 from 3.2 million in the previous quarter and the number of internet users had a growth of 18.6 percentage (CCK, 2011). The respondents also indicated that all the payments made to the Council were done physically at the Town Hall or to the Municipal personnel. This was an indication that online payment options had not been explored. The receipts issued for the payments made at the Council were computer generated according to $91 \%$ of respondents while according to $9 \%$ the receipts were manual. This is an indication that the City Council is in a position to capture data on businesses. 
Typically, governments and top government officials are usually drivers, key influencers and decision makers of most smart city projects. Birmingham, Dublin, Gdansk and Shenyang offer good examples of projects where government and government agencies play this role (Kumar, 2010). The Government of Kenya established the e-governance Programme in June 2004 and has since then committed itself towards achieving an effective and operational e-governance system to facilitate better and efficient information and services delivery to the citizens, promote productivity among public servants and encourage participation of citizens in government (Outa, Etta, \& Aligula, 2006). E-governance is the use of technology to facilitate the operation of government and the dissemination of government information to the public who include the business fraternity. Menkveld, and Cobbett (2007), describe Local Government as providing platforms for productivity, entrepreneurship and economic modernization. In Kenya, community participation is made possible through the Local Authority Service Delivery Action Plans (LASDAP).

Kisumu City Council has adopted network technologies that include intranet, internet and management information system. Information Systems refer to software based tools networked with a combination of computer hardware, infrastructure and trained personnel to facilitate planning, control, coordination, and decision making in an organization. Local Authority Integrated Financial Operational management System (LAIFOMS) was an e-governance initiative for local governments through the Ministry of Local Government in Kenya. It is a computer based system that integrates financial and operational activities involving business transactions in the Local Authorities (LAs). The system is part of the Public Sector reform program focusing on improvement of financial management in LAs under the Kenya Local Government Reform Program (KLGRP). These Information Systems in addition to other IT initiatives were intended to catalyze the interactions of both the supply and demand side of the information market and enhance accessibility. A three-year case study of eight organizations found that information systems use within the organization was not simply a question of use or non-use, but rather that the utilization was complex, with transition and equilibrium periods (Payton \& Brennan, 1999).

The findings indicate that the Council had automated information on land rates through their LAIFOMS but the system had challenges with providing accurate data and had issues of double allocation. The Council also provided information on their regulations and by-laws on their website. The SEs were also interested in getting some business related information online that included supplies, tax, business resource opportunities, business information such as new products and supplies. Other areas of interest included public bulleting with current information about Kisumu and the technological advancements. The SEs were also keen on getting information on billing and details of services offered by the Council.

The research findings indicate that the automated receipting through the LAIFOMS had helped to cut down on fraud and loss of revenue as information available in the system was difficult to manipulate. Majority, $85 \%$ of SEs respondents, indicated that they make their payment for business permit yearly. Others make payments quarterly, monthly and daily. The manual receipts were also fed into the system and denominational coding used to avert fraud. However the Council did not have a well established backup system and were using Compact Diskettes as backup. The customer service and billing module in LAIFOMS meant to link up with the businesses was not enabled in the system as was designed to be. This corroborates the sentiments by Muganda, Ochara and VanBelle, (2008) that, Local authorities have continued the implementation of Local Authority Integrated Financial Operational Management System (LAIFOMS) without expressly considering how the LAIFOMs can be an infrastructure of use by the public.

Information systems have been successfully adopted by city authorities worldwide to develop, control and assess functions within the City for instance in Naga City in Philippines, information systems have been successfully adopted. The system had also been used to assess sustainability and integrate strategic concerns, such as community benefit, amenity, and sustainable development. Data on land supply and use was gathered to input to sustainability assessment and also to planning in the strategic domain. A monitoring team composed of the City Planning and Development Officer (CPDO) and the City Engineer's Office conducts on-site inspection, interprets land-related data to monitor developments on an ad-hoc basis (NCDP, 2000). Sixty nine upper and lower tier English local authorities have established regeneration information systems which provide information that serve $48 \%$ of population in England (Foley et al., 2007). Poland has been a user of geographic information and systems for many decades. The country's Head Office of Geodesy and Cartography first introduced a land information modernization program in the 1980s, today they are implementing an ESRI-based solution to support compliance with the European Unions Infrastructure for Spatial Information in Europe (INSPIRE) directive that will include a more integrated and unified distribution of spatial data services (Albin, 2003). 
Kisumu City Council according to the study has not reached the transformational stage of technology adoption. Hanna, Guy and Amold, (1995) used an analytical framework for information technology diffusion which identified the three technology diffusion phases as substitution, enhancement and transformation which is the ultimate and eventual realization of often unforeseen potential which open up opportunities for the re-definition of task via wholesome transformation of work practices and organizational structures. Substitution occurs when a new or improved technology merely substitutes for an existing one while enhancement occur when the new technology lead to substantial performance enhancement. The transformational stage of technology adoption would enable transformational changes which would involve use of technology to address sustainable and strategic concerns such as is the situation the developed countries cited. The effects of information technology would be considered as the changes that occur in a social system as a result of the adoption or rejection of an innovation (Rogers, 2003). These effects can be measured as the average changes in the knowledge, attitudes or overt behaviors regarding technology innovation by individuals in the system. Network technologies integrating utility services, citizens and the local authorities has gained prominence world over but evidently Kisumu City seems to be lagging behind in terms of using network technology in the wider City management and provision of timely services, utilities and market information exchange between the market players. The skewness of use of network technologies towards social information exchange causes the small businesses to miss out on the benefits provided by the technology and potentials of expanding business opportunities.

\subsection{Inhibitors to Use of Information Technology}

Inhibitors refer to the negatively oriented factors hindering the use of Information systems. The factors for failure of IT projects in governments can either be barriers or inhibitors as described by Khaled (2003), and Heeks (2003). An inhibitor plays two roles in discouraging usage, one, they act directly on beliefs about the consequences of use, that is, if a user perceives an inhibitor, they will judge the system to be difficult to use and not useful. The second role of inhibitors is that they will bias the positively oriented and symmetrically acting beliefs of the system as an object: system, information, and service quality (Cenfetelli, 2004).

The $45 \%$ of the SEs respondents with no internet connection gave the reason as lack of finances while other reasons given included lack of knowledge about internet resources but some indicated their businesses were too small and that internet connection was not necessary for them. Successful adoption of technology calls for strategic network technologies planning which requires not only financial investment but sensitization to create awareness on potentials of the technologies. The investment includes hardware; software products in addition network connectivity and sustainability. The investments must be backed by propelling nationwide and local policies for them to be viable as well as planned sensitization of the public on the opportunities. Information technology has become a strategic tool that enables corporations to accomplish their mission and objectives, strategic information technology planning (SISP) has been regarded as a critical issue in the management agenda since the 1980s (Doherty, Marples, \& Suhaimi, 1999). Based on a review conducted across 17 Sub-Saharan African Countries, the national objectives of achieving universal and affordable access to the full range of communications services have been undermined either by poor policies constraining market entry and the competitive allocation of available resources; weak institutional arrangements with a dearth of technical capacity and competencies; and in some instances, regressive taxes on usage (Calandro et al, 2010). The lots of opportunities for market information exchange can only be optimized if all the market players are aware of the existing opportunities through the various portals. Lack of awareness about the opportunities for information exchange via the various network technologies therefore becomes a serious drawback to technological advancement. One of the key inhibitors of the LAIFOMS compatibility given that LAIFOMS was programmed to run on Windows XP and therefore computers with Windows 8 had caused some loose of data. According to the IT department of the Council, the LAIFOMS was not easy to manipulate and error rectification was difficult because so many rights to modification were reserved. Another challenge noted was the double allocation of plots through the system and which the system was not able to detect. 


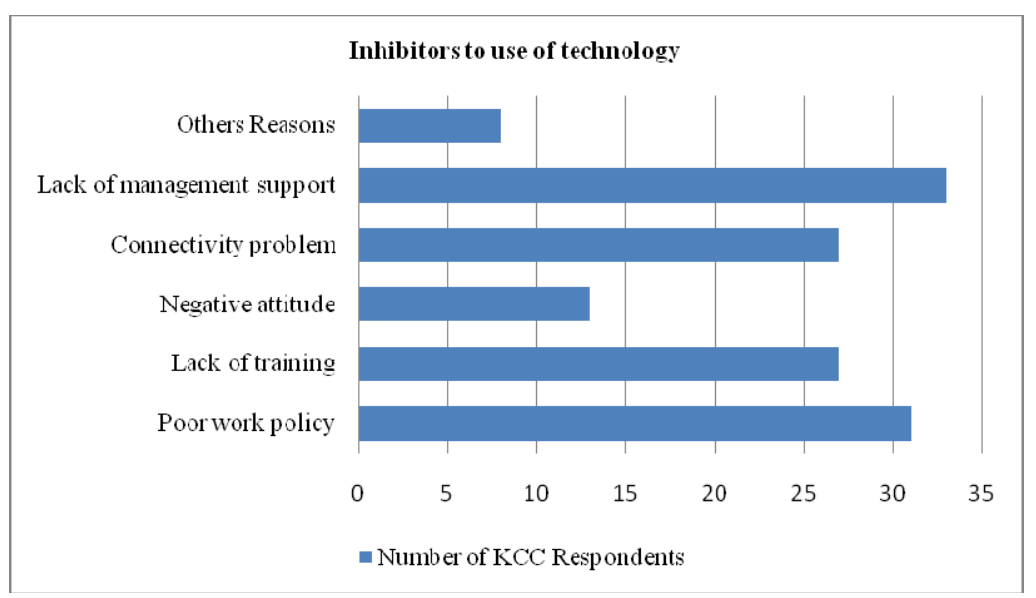

Figure 3. Inhibitors to use of technology by Council staff

As illustrated in figure 3, the major hindrances to use of technology mentioned by staff included lack of management support, poor work policy, lack of training and poor connectivity. King (2000), argued there are some significant enablers of SITP, including senior management involvement both in the planning process and in the implementation of plans; user involvement in the planning process; and the comprehensive of the IS plan. Hence, more commitment and involvement should produce greater success and have a positive impact on the achievement of SISP in the rapidly changing organizational and IT environment. Policy implementations which need to be in line with the national ICT policy and can only add value with unequivocal management support. The few staff who have undergone training in ICT have done so through self motivated and sponsored ventures.

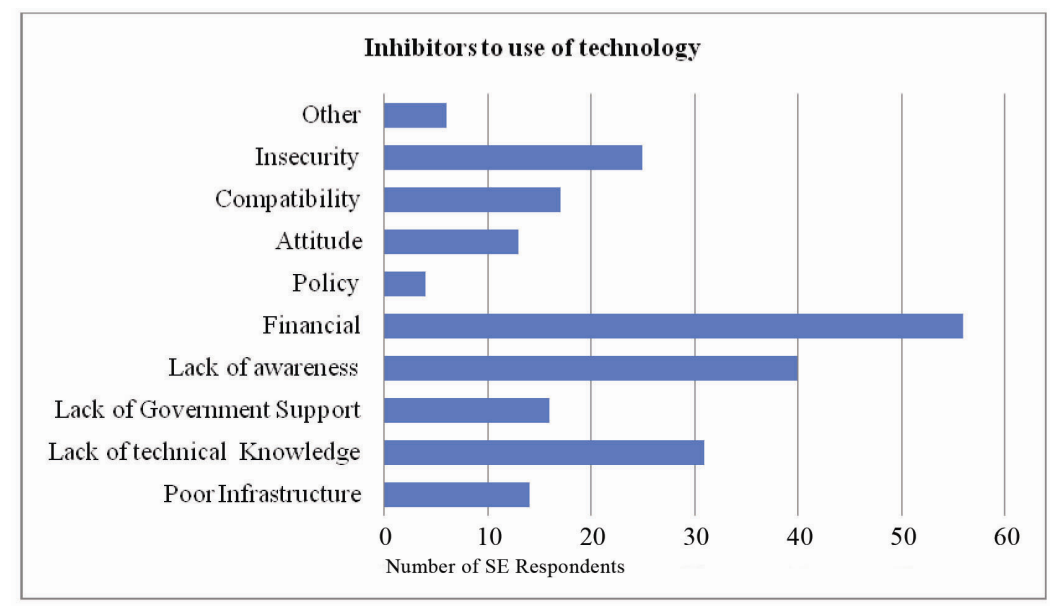

Figure 4. Inhibitors to use of IT in information exchange by SEs

Gillwald and Stock (2010) used a contingent valuation technique to understand the willingness and ability of individuals to pay for mobile services in 17 countries in Africa. The results confirmed that income is one of the main adoption barriers. Figure 4 indicates the most prominent inhibitors to use of IT by business enterprises were lack of financial resources clearly suggests that poor internet connectivity still remains a challenge to information exchange. Lack of awareness was the second most common inhibitor to use of technology. This involved the businesses inability to synchronize business opportunities with the available and adopted technologies and hence inability to use it to enhance their business potentials. Communications Commission of Kenya (2011) noted that the percentage of population that had internet access reached 25.9 per cent from 22.1 per cent reported in the previous quarter, representing an increase of 3.8 percent. Internet accessibility needs to grow commensurate with the demand for internet use. Internet accessibility via mobile phone technologies has gained prominence in Kenya and majority of respondents are able to access internet through their mobile phones. Despite a steady increase in 
internet data subscription due to the $3 \mathrm{G}$ services infrastructure still remains a big challenge. The number of internet subscriptions increased by $47 \%$ in the $2^{\text {nd }}$ quarter of $2010 / 2011$ and the growth was attributed to three mobile operators rolling out thie $3 \mathrm{G}$ services (CCK, 2011).

\section{Conclusion and Recommendation}

The City Council of Kisumu and the SEs had great opportunities existing for exchanging information through the use of network technologies but they have not put them to optimal use. Internet is a great enabler to exchange of information between the City Council and the businesses but was not to the optimal usage. The major network technology trends include use of internet through personal computers and mobile phones. Both the Kisumu City Council and the SEs are in the substitution stage of technology adoption which means that the new or improved technologies are merely substitutes for previous systems with a minimal enhancement but with no transformational effect. It was discovered that use of network technologies was more skewed towards social information exchange despite the potentials of the technologies to advance business opportunities and organizational efficiency. The greatest impediment to use of IT in information exchange was financial constraint, lack of awareness and poor infrastructure. It is recommended that the Kisumu City Council should sensitize and educate the businesses and the general public on the services available through the network technologies via use of Internet, website, mobile phone and other market information exchange avenues. The citizenry and particularly the business fraternity need more engagement while the online services need to be enhanced to include more information and interactions that can enhance information sharing. The government can improve access to information through the creation of data centres and use of mobile telephony for information dissemination and payment services. The government through the relevant agencies should also intervene to provide and improve infrastructure to enable faster and cheaper Internet connectivity since Internet connection is a great enabler for information exchange which can be done by fast tracking installation of broadband Integrated Services Digital Network internet connectivity.

\section{References}

Alam, S. M., Elisa, N., \& Abbas, K. (2008). Changing the Dynamics of Governance through ICTs. City District Government, Falsalabad, Pakistan.

Albin J. (2003). Polish National Geographic Information System. Ordnance Survey Cambridge Conference.

Beynon-Davies, P. (2002). Information Technology: An Introduction to Information in Organizations. Basingstoke, Palgrave.

Calandro, E., Gillwald, A., Moyo, M., \& Stork, C. (2010). African Telecommunication Sector Performance Review 2009/2010. Towards Evidence-Based ICT Policy and Regulations, Vol. 2, Policy Paper no. 5.

Caldeira, M. M., \& Ward, J. M. (2002). Understanding the successful adoption and us of IS/IT in SMEs: an explanation from Portuguese manufacturing industries. Information Systems Journal, 12(2), 121-152. http://dx.doi.org/10.1046/j.1365-2575.2002.00119.x

Cenfetelli, R. T. (2004). An Empirical Study of the Inhibitors of Technology Usage. The University of British Columbia Vancouver, BC Canada. Twenty-Fifth International Conference on Information Systems.

Communications Commision of Kenya. (2011). Quarterly Sector Statistics Report, 2nd Quarter October-December 2010/2011.

Davis, K. E., \& Addom, B. K. (2010). Sub-Saharan Africa. In R. Saravanan (Ed.), ICTs for agricultural extension: Global experiments, innovations and experiences. New Delhi: New India Publishing Agency.

Doherty, N. F., Marples, C. G., \& Suhaimi, A. (1999). The Relative Success of AlternativeApproaches to Strategic Information Systems Planning: An Empirical Analysis. Journal of Strategic Information Systems, 8(3), 263-283. http://dx.doi.org/10.1016/S0963-8687(99)00024-4

Foley, P., Alfonso, X., \& Wiseman I. (2007). Technology Benefits. Queens Printer, UK.

Gillwald, A., \& Stork, C. (2010). Towards Evidence-based ICT Policy and Regulation: ICT acess and usage in Africa. Research ICT Afric. Vol. 1, Policy Paper 2.

Hanna, N., Guy, K., \& Arnold E. (1995). The Diffusion of Information Technology: Experience of Industrial Countries and Lessons for Developing Countries. The World Bank, Washington DC. http://dx.doi.org/10.1596/0-8213-3216-3

Heeks, R. (2003). Causes of e-governance Success and Failure. University of Manchester.

ITU. (2010). World Telecommunication/ICT Development Report 2010. Monitoring The WSIS Targets-A 
mid-term review. International Telecommunication Union (ITU), Geneva Switzerland.

Jenson, M., Myers, M., \& Southwood, R. (2004). The Impact of ICT in Africa. Paper Prepared for the Commission for Africa.

Kenya National Bureau of statistics (KNBS), Kenya Population Census. (2009).

Khaled, M. (2003). Information Technology in Government Action Plan for Bangladesh. Retrieved from http://www.sITgov.org/IT

King, W. R. (2000). Assessing the efficacy of IS strategic planning. Journal of Information Systems Management, 17(1), 81-83. http://dx.doi.org/10.1201/1078/43190.17.1.20000101/31218.11

Kumar, Y., \& Mahaddalkar, M. (2010). Role of Telcom Operators in Smart Grid. Cranfield University School of Management.

Kwadwo, A. O., \& Mekonnen, D. A. (2012). The Importance of the ICTs in the Provision of Information for Improving Agricultural Productivity and Rural Incomes in Africa. UNDP.

Linde, F., \& Stock, W. G. (2011). Information Market: A strategic Guideline for the I-Commerce. Belin, New York. http://dx.doi.org/10.1515/9783110236101

Menkveld, P. A., \& Cobbett, W. (2007). Understanding Your Economy; A Resource Guide for Cities. Washington, DC: Cities Alliance.

Muganda, O., \& Van Belle, J. P. (2008). Managing the e-government Adoption process in Kenya's Local Authority. South Africa: University of Cape Town.

Naga City, Naga City Comprehensive Land Use Plan. (2000). (NCDP). Naga City Hall, Philippines, 2000.

Neun, D. H. (2006). Annual Report 2006. CTA -Technical Centre for Agricultural and Rural Cooperation $A C P-E U$. Wageningen, The Netherlands, CTA.

Outa, G., Etta, F., \& Aligula, E. (2006). Mainstreaming IT, Research Perspective from Kenya. Nairobi Kenya: Mvule Africa.

Payton, F. C., \& Brennan, P. F. (1999). How a Community Health Information Network is Really used. Communication of the ACM 42. No. 12, 85-89. http://dx.doi.org/10.1145/322796.322814

Pyramid Research. (2010). The Impact of Mobile Services in Nigeria: How Mobile Technologies Are Transforming Economic and Social Activities. Retrieved June 7, 2011, from http://www.pyramidresearc.com/documents/IMPACTof MobileServicesIn NIGERIA.pdf

Rogers, E. M. (2003). Diffusion of Innovation, Fifth Edition. USA: Free Press

Simrad, A. J. (2005). Global Disaster Information Network. UN World Conference on Disaster Reduction. Kobe, Japan.

Waema, T. M., \& Mitullah, W. (2007). E-governance and government: A case study of the assessment of the effects of integrated financial management system on good governance in two City Councils in Kenya.

Webb, M., Buschev, V., \& Giles, S. (2011). Information Marketplaces. The New Economics of Cities. The Climate Group, ARUP. Accenture and Horizon, University of Nottingham.

World Bank. (2009). Report on Information and Communication for Development (IC4D) Extending Reach and Increasing Impact. Retrieved from http://www.infordev.org/en/Article.384.htm

Wymer, S. A., \& Regan, E. A. (2005). Factors influencing e-commerce adoption and use by small and medium businesses. Electronic Markets, 15(4), 438-453. http://dx.doi.org/10.1080/10196780500303151

\section{Appendix A}

$\begin{array}{ll}\text { Abbreviations } & \\ \text { CBD } & \text { Central Business DistrIT } \\ \text { CiRM } & \text { Citizen Relationship Management } \\ \text { CPDO } & \text { City Planning \& Development Office } \\ \text { ESRI } & \text { Economic and Social Research Institute } \\ \text { GIS } & \text { Geographic Information System }\end{array}$




$\begin{array}{ll}\text { IS } & \text { Information System } \\ \text { IT } & \text { Information Technology } \\ \text { INSPIRE } & \text { Infrastructure for Spatial Information in Europe } \\ \text { KCC } & \text { Kisumu City Council } \\ \text { KLGRP } & \text { Kenya Local Government Reform Program } \\ \text { KUP } & \text { Kisumu Urban Project } \\ \text { LAIFOMS } & \text { Local Authority Integrated Financial Operational Management System } \\ \text { LA } & \text { Local Authority } \\ \text { LASDAP } & \text { Local Authority Service Delivery Action Plans } \\ \text { SEs } & \text { Medium and Small Enterprises } \\ \text { MIS } & \text { Management Information System } \\ \text { NCDP } & \text { Naga City Development Plan } \\ \text { SITP } & \text { Strategic Information Technology Planning }\end{array}$

\section{Copyrights}

Copyright for this article is retained by the author(s), with first publication rights granted to the journal.

This is an open-access article distributed under the terms and conditions of the Creative Commons Attribution license (http://creativecommons.org/licenses/by/3.0/) 